REFERENCES

BORING, F. W., \& MORROW, M. C. Effects of UCS intensity upon conditioning and extinction of the GSR. Journal of Experimental Psychology, 1968, 77. 566-571.

FISHBEIN, H. D., \& LeBLANC, M. Human eyelid conditioning as a function of ISI. Joumal of Experimental Psychology $1967,75,130-133$.

GRICE, G. R., \& HUNTER, J. J. Stimulus intensity effects depend upon the type of experimental design. Psychological Review, 1964, 71, 247-256.

KIMBLE, G. A. Conditioning as a function of the time between conditioned and unconditioned stimuli. Journal of Experimental Psychology, 1947, 37, 1-15.

KIMBLE, G. A., LEONARD, T. B., III, \& PERLMUTER, L. C. Effects of interstimulus interval and discrimination learning in eyelid conditioning using between- and within-S designs. Journal of Experimental Psychology, 1968, 77, 65 2-660.
MORROW, M. C.. \& KEOUGH, T. E., III. GSR conditioning with long interstimulus intervals. Journal of Experimental Psychology, 1968, 77, 460-467.

OMINSKY, M. Differential instructions and interstimulus interval in eyelid conditioning. Psychonomic science, 1968. 12, 51-52.

PROKASY, W. F., FAWCETT, J. T., \& HALL, J, F. Recruitment, latency, magnitude, and amplitude of the GSR as a function of interstimulus interval. Journal of Experimental Psychology, $1962,64,513-518$.

WICKENS, D. D., ALLEN, C. K., \& HILL, F. A. Effect of instructions and UCS strength on extinction of the conditioned GSR. Journal of Experimental Psychology, 1963, 66, 235-240.

WICKENS, D. D., \& HARDING, G. B. Effect of UCS strength on GSR conditioning: A within-subject design. Journal of Experimental Psychology, $1965,70,151-153$.

\section{Interpersonal attraction as a function of attitude similarity dissimilarity and attitude extremity}

\author{
LEE A. JACKSON and GUILLERMO F. MASCARO \\ University of Florida, Gainesville, Fla. 32601
}

This experiment tested the effects of attitude extremity on the functional relationship between level of attitude similarity and interpersonal attraction. It was predicted that persons exhibiting greater attitude extremity would be more attracted to a "bogus" stranger who expressed similar attitudes and less attracted to a stranger expressing dissimilar attitudes than Ss holding more neutral attitudes. The results showed a significant main effect of attitude similarity on attraction, but the hypothesized interaction with attitude extremity was not found to be significant. The data were discussed in the context of other findings in the area.

Recent field and laboratory research across widely different experimental conditions has confirmed the hypothesis that interpersonal attraction is functionally related to attitude similarity (Berscheid \& Walster, 1969; Byrne, 1969; Newcomb, 1961). However, with the exception of a few studies (e.g., Byrne, 1965), there has been little focus on individual differences among $\mathrm{Ss}$ and their interactions with similarity in determining attraction. One of such parameters that needs to be investigated is the extremity of position of the experimental $S$ on the attitude items in which a stranger expresses attitude similarity or dissimilarity. addition, most authors consider those magnitudinal properties and their relationships to behavior to be among the most relevant functional characteristics of attitudes.

Interestingly enough, such a preeminent concept in the attitude literature as "topic importance" "has not been consistently found to affect the similarity-attraction relationship. In several incisive experiments, Byrne and his associates have demonstrated that the importance of the issue on which agreement occurred affected attraction (i.e., interacted with attitude similarity) only when the same person agreed/disagreed on items of different importance (Byrne, London, \& Griffitt, 1968; Clore \& Baldridge, 1968) but not when the importance of the items differed for different target persons and the items on which a given person agreed/disagreed had a uniform level of importance (Byrne \& Nelson, 1964,1965 ). Thus, apparently, the effects of topic importance, at least as a stimulus-manipulated variable, are limited only to certain paradigms of agreement-disagreement (e.g., the so-called intrastranger design).

Recently, Gormley \& Clore (1969) investigated the effects on attraction of agreement-disagreement in different items on which the Ss exhibited extreme or neutral responses. The types of items (i.e., extreme or neutral) on which a bogus stranger agreed/disagreed with the Ss did not affect attraction scores. However, this study did not address itself to determining the effects of attitude extremity as an organismic or individual-differences variable (i.e., the S's attitude extremity on a given issue).

The purpose of the present experiment is to test the effects of attitude extremity, as an organismic variable, on the similarity-attraction relationship. Based on the theoretically and empirically established relationship between extremity and other magnitudinal properties of attitudes (i.e., intensity, importance, degree of ego involvement, etc.), it can be predicted that the Ss' attitude extremity will affect the similarity-attraction function. Specifically, it is hypothesized that persons holding more extreme attitudes will develop greater attraction to those persons who express similar attitudes and lower attraction to those with discrepant attitudes than will persons who hold more neutral positions.

Since the "importance" variable has been found to be highly susceptible to experimental design variations (Byrne, 1969), testing the effects of extremity under the methodological conditions of this experiment (i.e., measuring 
individual differences in attitude extremity) should help to establish the extent to which magnitudinal properties of attitudes are relevant parameters of the functional relationship between attitude similarity and interpersonal attraction. SUBJECTS

The Ss were 120 male and female undergraduate students from an introductory psychology course at the University of Florida. Twelve Ss (four from each level of similarity) were eliminated either because postexperimental questionnaires revealed understanding of the hypothesis or for failure to follow in structions.

\section{PROCEDURE}

The Ss were recruited for an experiment on "interpersonal prediction." After answering a Florida political beliefs scale (PBS) (Shaw \& Wright, 1967), each $S$ was given several irrelevant questionnaires to fill out and while he was completing this task, a second $\mathrm{E}$ was preparing a bogus PBS which reflected $20 \%, 50 \%$, or $80 \%$ agreement, depending on the condition to which the $S$ had been assigned. The discrepancy manipulation was performed by displacing the responses on a given number of items 3 scale units (on a 5-point Likert-type scale) away from the S's answers. Finally, the $S$ was given the PBS, presumably answered by another $S$, with instructions stating that he was engaged in an experiment on "interpersonal prediction" and that his task was to rate (on a series of scales provided) the person who had answered the PBS. The $S$ then gave his ratings on the interpersonal judgment scale (IJS) (Byrne, 1961), which includes a measure of attraction (i.e., ratings of liking and desire to work together) plus other items dealing with interpersonal evaluation (i.e., intelligence, knowledge of current events, morality, and adjustment).

\section{RESULTS}

Analyses of variance were performed on the attraction scores and on the (total) evaluation scores, based on three degrees of agreement (20\%, $50 \%$, and $80 \%$ ) and two levels of extremity (high and low). The results are shown in Tables 1 and 2. A significant main effect of agreement on both the attraction scores (sum of items on liking and coworking, $\mathrm{F}=18.72, \mathrm{df}=2 / 102, \mathrm{p}<.01)$ and the total evaluation scores (sum of all items in the PBS, $F=27.78$, $\mathrm{df}=2 / 102, \quad \mathrm{p}<.01$ ) was found, demonstrating again the ubiquity of the similarity-attraction relationship. A nonsignificant trend appeared for the main effect of extremity on the total evaluation scores, and no trend or significant effect of extremity was
Table 1

Means of Attraction Scores for Three Degrees of Similarity and Two Levels of Attitude Extremity

\begin{tabular}{llll}
\hline & \multicolumn{3}{c}{ Degree of } \\
\cline { 2 - 4 } \multicolumn{1}{c}{ Mean } & .20 & .50 & .80 \\
\hline $\begin{array}{l}\text { High } \\
\text { Extremity }\end{array}$ & 5.11 & 7.11 & 8.28 \\
$\begin{array}{l}\text { Low } \\
\text { Extremity }\end{array}$ & 5.78 & 6.89 & 8.84 \\
\hline
\end{tabular}

Table 2

Means of Total Evaluative Scores for Three Degrees of Similarity and Two Levels of Attitude Extremity

\begin{tabular}{lccc} 
& \multicolumn{3}{c}{ Degree of Similarity } \\
\cline { 2 - 4 } \multicolumn{1}{c}{ Mean } & .20 & .50 & .80 \\
\hline $\begin{array}{l}\text { High } \\
\text { Extremity }\end{array}$ & 17.28 & 20.50 & 25.11 \\
$\begin{array}{l}\text { Low } \\
\text { Extremity }\end{array}$ & 19.67 & 21.78 & 26.06 \\
\hline
\end{tabular}

found on the attraction scores. Finally, contrary to predictions, no significant interaction was found between extremity and agreement on the attraction or on the evaluation scores.

\section{DISCUSSION}

The failure to obtain the predicted extremity interaction on the similarity-attraction relationship might be viewed in different ways. One alternative is that the subpopulation from which the sample was drawn may not have included a representative number of highly ego-involved Ss. In accord with this position, some authors have contended that college volunteer $S$ s give low extremity responses (Rosenthal \& Rosnow, 1969), and others have suggested that the effects of extremity are found only when actually existing groups with high levels of involvement are selected for investigation (Zimbardo \& Ebbesen, 1969).

Another possibility is that the effect of attitude similarity is so powerful that individual differences among Ss do not produce any significant variation in attraction. A number of studies have failed to demonstrate the influence of individual difference variables (e.g., dogmatism, authoritarianism, and conceptual complexity) on the similarityattraction function (Baskett, 1966, 1968; Byrne, 1965). Also, in Nelson's (1965) unpublished doctoral dissertation, no relationship was found between levels of extremity and attraction. Taken together, the results of these experiments seem to suggest that the similarity-attraction relationship is resistant to individual differences and definitely point out the particular significance of attitude similarity in determining interpersonal attraction.

\section{REFERENCES}

BASKETT, G. D. Dogmatism and response to attitude similarity-dissimilarity. Unpublished Master's thesis, University of Texas, 1966

BASKETT, G. D. Interpersonal attraction as a function of at itude similarity-dissimilarity and cognitive complexity. Unpublished doctoral dissertation, University of Texas, 1968. BERSCHEID. E., \& WALSTER, E. Interpersonal attraction. Reading, Mass: Addison-Wesley, 1969 .

BYRNE, D. Interpersonal attraction and attitude similarity. Journal of Abnormal \& Social Psychology, 1961, 62, 713-715.

BYRNE, D. Authoritarionism and response to attitude similarity-dissimilarity. Journal of Social Psychology, 1965, 66. 251-256.

BYRNE, D. Attitudes and attraction. In $L$. Berkowitz (Ed.), Advances in experimental social psychology. Vol. 4. New York: Academic Press, 1969. Pp. 36-90.

BYRNE, D., LONDON, 0 . \& GRIFFITT, W. The effect of topic importance and attitudinal similarity-dissimilarity on attraction in the intrastranger design. Psychonomic Science, 1968, 11 303-304.

BYRNE, D., \& NELSON, D. Attraction as a f u $n$ c $i \circ n$ of at $i t u d e$ similarity-dissimilarity: The effect of topic importance. Psychonomic Science. $1964,1,93-94$.

BYRNE, D \& NELSON, $D$. The effect of topic importance and attitude similarity-dissimilarity on attraction in a multistranger design. Psychonomic Science, 1965, 3, 449-450.

CLORE, G.. \&: BALDRIDGE, B. Interpersonal attraction: The role of agreement and topic interest. Journal of Personality \& Social Psychology, 1968, 9. 340-346.

GORMLY. A., \& CLORE, G. Attraction. dogmatism, and attitude similarity-dissimilarity. Journal of Experimental Research in Personality. $1969,4,9-13$.

HOLLANDER, E. Principles and methods of social psychology. New York: Oxford University Press, 1967.

NELSON, D. The effect of differential magnitude of reinforcement on interpersonal attraction. Unpublished doctoral dissertation. University of Texas, 1965.

NEWCOMB, T. The acquaintance process. New York: Holt, Rinehart \& Winston, 1961 .

NEWCOMB, T., TURNER, R., \& CONVERSE, P. Social psychology. New York: Holt, Rinehart \& Winston, 1965 OSGOOD, C, E., SUCI, G. J., \& TANNENBAUM, P. H. The measurement of meaning. Urbana, Ill: University of Illinois Press, 1957

ROSENTHAL, R., \& ROSNOW, R. The volunteer subject. In $R$. Rosenthal and $R$. Rosnow (Eds.), Artifact in behavioral research. New York: Academic Press, 1969. Pp. 59-118.

SHAW, M. E., \& WRIGHT, J. Scales for the measurement of attitudes. New York: McGraw-Hill, 1967.

SHERIF, M., \& SHERIF, L. Social psychology. New York: Harper \& Row, 1969.

WEKSEL, W., \& HENNES, J. D. Attitude intensity and the semantic differential. Journal of Personality \& Social Psychology, 1965, 2, 91-94.

ZIM BARDO, P., \& EBBESEN, F Influencing attitudes and changing behavior. Reading, Mass: Addison-Wesley, 1969 . 